\title{
Performance of Probiotic Bacterium, Enterococcus gallinarum Enriched Artemia franciscana Nauplii on Survival, Growth and Basic Biochemical Constituents of the Prawn Macrobrachium rosenbergii Post Larvae
}

\author{
Jain IB, Saravana Bhavan P*, Kalpana R, Manjula T, Dharani C, Muralisankar T, Veerapandi A, Karthik M
}

Department of Zoology, Bharathiar University, Coimbatore - 641046, Tamil Nadu, India

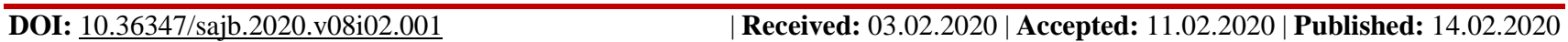

*Corresponding author: Dr. P. Saravana Bhavan

Abstract

Original Research Article

This work was emphasized the growth performance of the prawn, Macrobrachium rosenbergii post larvae (PL) fed with a probiotic bacterium, Enterococcus gallinarum enriched Artemia franciscana nauplii at five different serially diluted concentrations $\left(10^{-1}, 10^{-3}, 10^{-5}, 10^{-7}\right.$ and $\left.10^{-9}\right)$. A 45 day, feeding trial, showed significantly $(\mathrm{P}<0.05)$ increased survival rate, growth rate, contents of total protein, amino acid, carbohydrate and lipid, and activities of digestive enzymes (protease, amylase and lipase) in test prawns, particularly at $847 \times 10^{-7}$, CFU. At this concentration, the consortium of the gut microflora of unenriched Artemia nauplii fed prawn showed the presence of E. coli; Klebsiella sp., Citrobacter sp., Acinetobacter sp., Streptococcus sp., Bacillus sp., Staphylococcus sp., and Pseudomonas sp. But in E. gallinarum enrich Artemia nauplii fed PL showed the presence of Enterococcus sp., Streptococcus sp., E. coli, Bacillus sp., and Klebsiella sp. Thus, it was found the pathogenic bacteria, Citrobacter sp., Acinetobacter sp., Staphylococcus sp., and Pseudomonas sp., were replaced due to the colony establishment of Enterococcus sp., in test prawns. Hence, E. gallinarum can be used as a probiotic for sustainable culture of $M$. rosenbergii.

Keywords: Prawn, E. gallinarum, Artemia, growth, survival, protein.

Copyright @ 2020: This is an open-access article distributed under the terms of the Creative Commons Attribution license which permits unrestricted use, distribution, and reproduction in any medium for non-commercial use (NonCommercial, or CC-BY-NC) provided the original author and source are credited

\section{INTRODUCTION}

The production of marine and freshwater crustaceans contributes $17.3 \%$ and $4.5 \%$, respectively [1] in world aquaculture. Crustaceans possess physiological and/or behavioral adaptation strategies to survive under a plethora of conditions and these adaptations may be specific for the species, feeding habits, gender, food availability and molting cycle [2]. The giant river prawn, Macrobrachium rosenbergii, the largest and fastest growing prawn species, is cultured either under monoculture or polyculture with major carps. Commercially important freshwater prawns in India are $M$. rosenbergii, Macrobrachium malcolmsonii and Macrobrachium gangeticum.

The probiotics as living microbial cells added as dietary supplements for aquaculture. These beneficial bacteria preferably displace pathogenic bacteria through competitive [3-5]. Enterococci belong to the lactic acid bacteria have been used widely in the food industry as probiotics [6, 7]. Some strains of Enterococcus faecium and Enterococcus faecalis are used as probiotics and are ingested in high numbers, generally in the form of pharmaceutical preparations. In human, these probiotics are administered to treat diarrhoea, antibiotic-associated diarrhoea or irritable bowel syndrome, to lower cholesterol levels, to improve host immunity etc., [8]. Furthermore, Enterococcus genus is isolated from the intestine of common carp and fresh water prawn $M$. rosenbergii [9]. In the present study, Artemia franciscana nauplii was enriched with Enterococcus gallinarum and fed to $M$. rosenbergii PL as a live feed for assessing their survival rate, growth performance, content of basic biochemical constituents and activities of digestive enzymes, protease, lipase and amylase.

\section{MATERIALS AND METHODS}

Procurement of Enterococcus gallinarum (7049) and its sub culture

The lyophilized powder of E. gallinarum (MTCC 7049) was purchased from Microbial Type Culture Collection (MTCC), Chandigarh, India. It was subjected to sub-culture with Nutrient broth (Hi-media, India, $\mathrm{pH}$, 6.5 at Temperature, $25^{\circ} \mathrm{C}$ ), contained peptic digestion of animal tissues $\left(5 \mathrm{~g} \mathrm{~L}^{-1}\right)$, Beef extract $\left(1.5 \mathrm{~g} \mathrm{~L}^{-1}\right)$, Sodium chloride $\left(5.0 \mathrm{~g} \mathrm{~L}^{-1}\right)$, and yeast extract $\left(1.5 \mathrm{~g} \mathrm{~L}^{-1}\right)$. The culture medium was prepared and treated according to the manufacturer's protocol. The medium $(13 \mathrm{~g})$ was 
mixed with $1000 \mathrm{~mL}$ of distilled water, enclosed in a screw cap container and autoclaved at $121^{\circ} \mathrm{C}$ for 15 minutes. The probiotic E. gallinarum was inoculated into the broth and it was incubated for 24 hours at $37^{\circ} \mathrm{C}$ in a shaking incubator for its growth activity. The clear broth turned into turbid, which indicates the growth of $E$. gallinarum (Figure 1). After incubation, the $E$. gallinarum cells were harvested by centrifugation (5000 rpm, $10 \mathrm{~min}$ ), washed twice with phosphate buffered saline ( $\mathrm{pH}, 7.2)$, weighed and re-suspended in the same buffer. It was stored at $4{ }^{\circ} \mathrm{C}$, and used for further study. $30 \mu \mathrm{l}$ of suspension was spread over the agar plate. The appearance of white colonies was observed (Figure. 2). The broth was serially diluted up to $10^{-9}$ and $20 \mu \mathrm{l}$ was spread on nutrient agar to enumerate the CFU in each dilution in order to optimize it, which showed presence 2078 colonies at $10^{-1}$ dilution, 1774 at $10^{-3}, 1061$ at $10^{-5}$, 847 at $10^{-7}$, and 547 at $10^{-9}$.

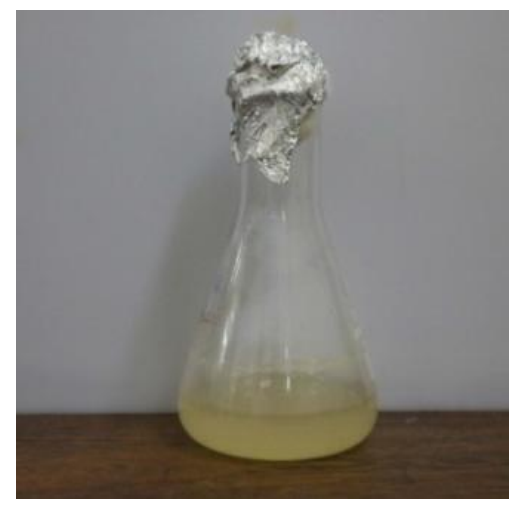

Fig-1: Mother culture morphology of E. gallinarum

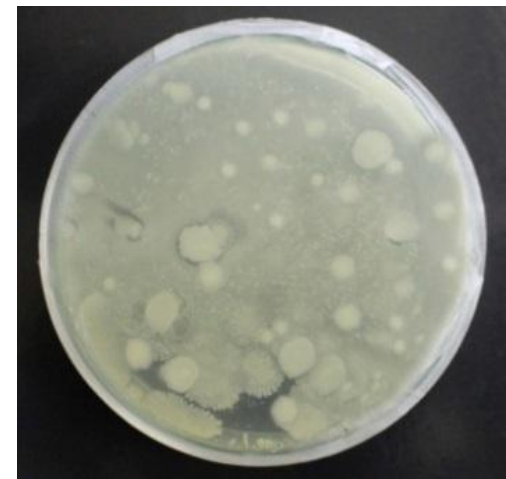

Fig-2: Spread plate culture morphology of $E$. gallinarum on nutrient agar

\section{Feed preparation}

The micro pulverized and sieved $(0.3 \mathrm{~mm})$ basal ingredients, such as fishmeal $(25 \%)$, groundnut oil cake (25\%), and soybean meal (25\%) were used as protein sources; wheat bran (10\%) was used as carbohydrate source. These ingredients were taken at different ratio based on Pearson's square method to maintain 40\% protein level and thoroughly mixed. The mixed feed ingredients were steam cooked for $15 \mathrm{~min}$ at $95-100^{\circ} \mathrm{C}$ and allowed to cool at room temperature. In such a way diets were prepared. Vitamin B complex with vitamin C (1\%) was added in the form of BECOSULES CAPSULES (Pfizer Ltd., Mumbai, India). Each capsule contains: Thiamine mononitrate (IP) $10 \mathrm{mg}$; Riboflavin (IP) $10 \mathrm{mg}$; Pyridoxine hydrochloride (IP) $3 \mathrm{mg}$; Vitamin B12 (as tablets 1:100) (IP) 15 mcg; Niacinamide (IP) $100 \mathrm{mg}$; Calcium pantothenate (IP) 50 $\mathrm{mg}$; Folic acid (IP) $1.5 \mathrm{mg}$; Biotin (USP) $100 \mathrm{mcg}$; Ascorbic acid (IP) $150 \mathrm{mg}$. Tapioca flour (5\%) and egg albumin (7\%) were used as binding agents, and sunflower oil (2\%) was added as lipid source. Dough was prepared with $10 \%$ boiled water and pelletized in a manual pelletizer fixed with $3 \mathrm{~mm}$ diameter and pellets were collected in aluminum trays. Then the feed was dried under room temperature until the moisture content reached less than $10 \%$. The feed was physically examined for visual appearance, such as uniformity, color and fragrance. The pellets were with smooth surface. The prepared feed was subjected for the analyses of proximate compositions and mineral contents (Table 1).

Table-1: Proximate compositions and mineral contents in the basal diet formulated

\begin{tabular}{|l|c|}
\hline \multicolumn{1}{|c|}{ Proximate composition } & $(\mathbf{\%})$ \\
\hline Crude protein & 46.79 \\
\hline Total Nitrogen-free extract & 32.21 \\
\hline Ether extract (Crude fat) & 6.19 \\
\hline Crude fiber & 1.33 \\
\hline Ash & 6.81 \\
\hline Moisture & 9.84 \\
\hline Gross energy Minerals & $4443 \mathrm{kcal} / \mathrm{kg}$ \\
\hline \multicolumn{1}{|c|}{} \\
\hline $\begin{array}{l}\text { Sand and silica (Acid insoluble } \\
\text { ash) }\end{array}$ & 0.88 \\
\hline Calcium & 0.80 \\
\hline Phosphorus & 0.90 \\
\hline Iron & 0.11 \\
\hline Copper & 0.002 \\
\hline Salt & 0.58 \\
\hline
\end{tabular}

Enrichment of Artemia nauplii with $\boldsymbol{E}$. gallinarum

The brine shrimp, A. franciscana cysts were purchased from Aqua world, Paris Corner, Chennai, India. The cysts $\left(2 \mathrm{~g} / 20 \mathrm{~L}\right.$ and $15 \mathrm{~g} \mathrm{~kg}^{-1}$ body biomass of the prawns for feeding trial) were taken and hydrated in 1 $\mathrm{L}^{-1}$ of purified artificial saltwater (prepared from artificial sea salt powder $35.0 \mathrm{~g} \mathrm{~L}^{-1}$, $\mathrm{pH}$ of 6.5). After 12-15 h, the cysts burst, and the embryo surround by the hatching membrane become visible. After a few hours, the brownish orange colored nauplii came out. The 48-hr old Artemia nauplii were filtered and transferred to $1 \mathrm{~L}$ capacity glass beaker. Five such groups were enriched with $2078 \times 10^{-1}, 1774 \times 10^{-3}, 1061 \times 10^{-5}, 847 \times 10^{-7}$, and $547 \times 10^{-9}$ concentrations of E. gallinarum for 1 hour (Fig.3). Then they were washed with freshwater and fed to $M$. rosenbergii $\mathrm{PL}$. 


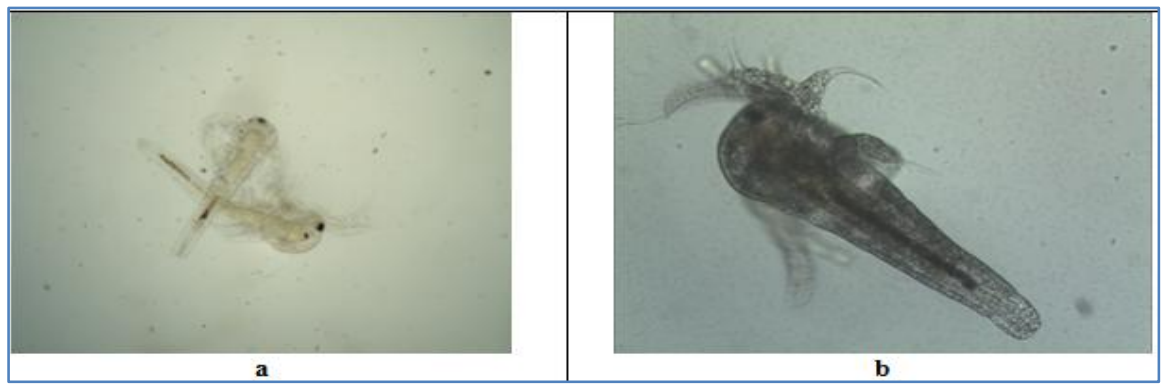

Fig-3: 24 hrs. old $A$. franciscana nauplii. a, Un-enriched; b, Enriched with $E$. gallinarum

\section{Procurement and acclimatization of experimental animal}

The post larvae (PL-8) of the freshwater prawn, $M$. rosenbergii were procured from a prawn culture nursery pond, Marakkanam, Chennai, India. They were transported to the laboratory in polythene bags filled with oxygenated water. The prawns were acclimatized to the ambient laboratory condition in cement tanks with ground water for two weeks. The diluent control (ground water) had these physicochemical parameters: Temperature $\left({ }^{\circ} \mathrm{C}\right), 28 \pm 2.2 ; \mathrm{pH}, 7.4 \pm 0.10 ; \mathrm{TDS}(\mathrm{g} / \mathrm{L})$, $0.94 \pm 0.05 ;$ DO $(\mathrm{mg} / \mathrm{L}), 4.25 \pm 0.25$; Salinity $(\mathrm{mg} / \mathrm{L})$, $0.70 \pm 0.02 ;$ EC $(\mathrm{Ms} / \mathrm{cm}), 1.01 \pm 0.01$ and Ammonia $(\mathrm{mg} / \mathrm{L}), 0.028 \pm 0.006$. During acclimatization the prawns were fed with boiled egg albumin and artificially formulate feed (our laboratory prepared feed). More than $50 \%$ of tank water was routinely renewed every day in order to maintain a healthy environment and aeration was provided. This ensures sufficient oxygen supply to the prawns and an environment devoid of accumulated metabolic wastes. The unfed feeds, faecal material, exuvia and moults, and dead prawns if any were removed by siphoning without disturbing the prawns.

\section{Feeding trail}

The PL of $M$. rosenbergii ranged from $1.1 \pm 0.05 \mathrm{~cm}$ in length and $0.05 \pm 0.003 \mathrm{~g}$ of body mass were taken. They were divided into seven groups, PL fed with artificial feed (group 1) PL fed with unenriched Artemia nauplii (group 2), and groups 3-7, PL fed with E. gallinarum $\left(2078 \times 10^{-1}, 1774 \times 10^{-3}, 1061 \times 10^{-5}\right.$, $847 \times 10^{-7}$, and $547 \times 10^{-9}$ ) enriched Artemia nauplii. Each group consist of 30 individuals filled with $25 \mathrm{~L}$ of ground water. The water medium was renewed every $24 \mathrm{hrs}$ by siphoning method without severe disturbance to the prawn and aerated adequately. During feeding trial, the feces and moult were removed while renewing aquarium water. The experiment was extended for a period of 45 days. At the end of the feeding trial the final length and weight were measured for calculating nutritional indices and estimating basic biochemical constituents. The water medium was aerated adequately.

\section{Calculation of nutritional indices}

The survival rate (SR), length gain (LG), weight gain (WG), and specific growth rate (SGR) were individually calculated Tekinay \& Davis, [10].
Survival $(\%)=$ Total No. of live animals/Total No. of initial animals $\times 100$

Length gain $(\mathrm{cm})=$ Final length $(\mathrm{cm})-$ Initial length $(\mathrm{cm})$

weight $(\mathrm{g})$

Weight gain $(\mathrm{g})=$ Final weight $(\mathrm{g})-$ Initial

$\mathrm{W} 1 / \mathrm{t} \times 100$

Specific growth rate, $(\%)=\log \mathrm{W} 2-\log$

Where, W1 \& W2 = Initial and Final weight respectively $(\mathrm{g})$, and $\mathrm{t}=$ Total number of experimental days.

\section{Estimations of basic biochemical constituents}

The initial and final concentrations of basic biochemical constituents, such as total protein, amino acid and carbohydrate were estimated in test prawns adopting the methodology of Lowry et al. [11], Moore \& Stein, [12] and Roe, [13], respectively, and the total lipid was extracted gravimetrically following the method of Folch et al. [14] and estimated by adopting the method of Barnes \& Blackstock, [15]. The contents of ash and moisture were analysed by following AOAC [16] methodology.

\section{Assays of digestive enzymes activities}

Activities of digestive enzymes (protease, amylase and lipase) were assayed at $45^{\text {th }}$ day of feeding trial. The digestive tract of three prawns from each replicate were carefully dissected out and homogenized in ice-cold distilled water and centrifuged at $9000 \mathrm{~g}$ under $4^{\circ} \mathrm{C}$ for $20 \mathrm{~min}$. The supernatant was used as a source of crude enzyme. Total protease activity was determined by casein-hydrolysis method of Furne et al. [17], where one unit of enzyme activity represented the amount of enzyme required to liberate $1 \mu \mathrm{g}$ of tyrosine per minute. Amylase activity was determined according to Bernfeld [18], the specific activity of amylase was calculated as milligrams of maltose liberated per gram of starch per hour (mg/g/h). Lipase activity was assayed by the method of Furne et al. [17], one unit of lipase activity was defined as the amount of free fatty acid released from triacylglycerol per unit time.

\section{Gut microbial colonization}

The gut of control prawns and the gut of experimental prawns fed with the best concentration of E. gallinarum $\left(847 \times 10^{-7}\right)$ were subjected to bacterial culture. The prawns were deactivated by keeping them in 
freezer at $20^{\circ} \mathrm{C}$ for 10 minutes. Then the surface was sterilized with $50 \mathrm{ppm}$ formalin for 30 seconds in order to remove the external flora. Then the digestive tract was dissected out individually and homogenized with phosphate buffered saline $(\mathrm{pH}, 7.2)$ under aseptic condition. Afterwards the homogenates were serially diluted up to $10^{-7}$ dilution individually. From this $0.5 \mathrm{~mL}$ of aliquots were taken and mixed with agar nutrient broth for $24 \mathrm{~h}$ at $35^{\circ} \mathrm{C}$. $0.1 \mathrm{ml}$ of broth culture was seeded over the surface of freshly prepared nutrient agar plates and incubated at $37{ }^{\circ} \mathrm{C}$ for $24 \mathrm{~h}$. The different bacterial colonies were identified and they were confirmed through routine bacteriological tests Holt et al. [19]. The following tests, such as Gram's staining, motility test, indole test, methyl red test, Voges Proskauer test, citrate utilization test, starch hydrolases, gelatin hydrolases, nitrate reduction test, oxidase test, catalase test and carbohydrate fermentation test were performed. The bacterial colony was enumerated with the formula, Bacteria count $(\mathrm{CFU} / \mathrm{g})=$ Number of colonies $\times$ Dilution factor/Volume of sample $(\mathrm{g})$.

\section{STATISTICAL ANALYSIS}

Data between control versus experiments and between experiments were subjected to statistical analysis through one-way ANOVA and subsequent post-hoc multiple comparison with DMRT by adopting SPSS (v20). All the details of statistical analyses were given in respective tables. The $P$ values less than 0.05 were considered as statistically $(95 \%)$ significant.

\section{RESULTS AND DISCUSSION}

\section{Survival rate and nutritional indices}

The survival rate (SR), and growth performance (LG, WG and SGR) were found to be significantly $(P<0.05)$ higher in serially diluted $\left(2078 \times 10^{-1}\right.$, $1774 \times 10^{-3}, 1061 \times 10^{-5}, 847 \times 10^{-7}$, and $\left.547 \times 10^{-9}\right) E$. gallinarum enriched Artemia nauplii fed to prawns when compared with un-enriched Artemia and the PL fed with pelletized feed. Among different concentrations of $E$. gallinarum, $847 \times 10^{-7}$ produced the best growth performance (Table 2; Fig. 2).

Mahmood et al. [20] observed that Artemia enriched with symbiotic bacteria Pediococcus acidilactici and Fructooligo saccharide fed Angelfish (Pterophyllum scalare) juvenile improves growth performance. Salem Ahmed et al. [21] reported in European sea bass (Dicentrarchus labrax) that significantly $(\mathrm{p}<0.05)$ higher total length gain and survival, growth rate when treated with green water plus marine probiotic bacteria $(\mathrm{G}+\mathrm{MP})$ enriched rotifers (Brachionus plicatilis) and Artemia nauplii. Bhavan et al.[22] reported that spirulina enrichment Artemia has produced better growth in $M$. rosenbergii than that of Yeast enriched Artemia. Similarly, Seenivasan et al. [23, 24] reported in $M$. rosenbergii post larvae fed with bio-encapsulated diet containing L. sporogenes, and Binifit $^{\mathrm{TM}}$ ) [23]. When parrot fish fed with the diet containing B. subtilis E20 $10^{8} \mathrm{CFU} \mathrm{kg} \mathrm{kg}^{-1}$ resulted in a significantly increased weight gain. This could have been due to the nutrient supplements and exo enzymes provided by $B$. subtilis E20 [25].

Table-2: Survival and growth of $M$. rosenbergii PL fed with pellet feed, un-enriched and $E$. gallinarum enriched Artemia nauplii for $\mathbf{4 5}$ days.

\begin{tabular}{|c|c|c|c|c|c|c|c|c|}
\hline \multirow[b]{2}{*}{ Parameter } & \multirow[b]{2}{*}{$\begin{array}{l}\text { Pelletized } \\
\text { feed }\end{array}$} & \multirow{2}{*}{$\begin{array}{c}\text { PL fed with } \\
\text { Un-enriched } \\
\text { Artemia } \\
\text { nauplii }\end{array}$} & \multicolumn{5}{|c|}{ PL fed with $E$. gallinarum enriched Artemia nauplii } & \multirow[b]{2}{*}{ F-value } \\
\hline & & & $\begin{array}{c}2^{2078 \times 10^{-1}} \\
\text { CFU }\end{array}$ & $\begin{array}{l}\text { 1774x10 }^{-3} \\
\text { CFU }\end{array}$ & $\begin{array}{c}1061 \times 10^{-5} \\
\text { CFU }\end{array}$ & $\begin{array}{c}847 \times 10^{-7} \\
\text { CFU }\end{array}$ & $\begin{array}{c}547 \times 10^{-9} \\
\text { CFU }\end{array}$ & \\
\hline SR (\%) & $71.77 \pm 1.92^{f}$ & $76.66 \pm 3.37^{\mathrm{e}}$ & $83.33 \pm 3.33^{\mathrm{d}}$ & $86.33 \pm 3.33^{\mathrm{c}}$ & $90.33 \pm 3.33^{\mathrm{ab}}$ & $92.22 \pm 1.92^{\mathrm{a}}$ & $91.11 \pm 1.92^{\mathrm{ab}}$ & 26.46 \\
\hline Length $(\mathrm{cm})$ & $1.33 \pm 0.06^{\mathrm{f}}$ & $1.67 \pm 0.06^{\mathrm{e}}$ & $1.86 \pm 0.11^{\mathrm{d}}$ & $2.00 \pm 0.10^{\mathrm{c}}$ & $2.48 \pm 0.20^{\mathrm{b}}$ & $3.28 \pm 0.10^{\mathrm{a}}$ & $2.33 \pm 0.05^{\mathrm{bc}}$ & 101.30 \\
\hline Weight (g) & $0.49 \pm 0.07^{\mathrm{e}}$ & $0.72 \pm 0.05^{\mathrm{cd}}$ & $0.94 \pm 0.05^{\mathrm{c}}$ & $1.23 \pm 0.11 b^{c}$ & $1.39 \pm 0.07^{b}$ & $1.60 \pm 0.32^{\mathrm{a}}$ & $1.32 \pm 0.04^{\mathrm{bc}}$ & 24.34 \\
\hline LG (cm) & $0.33 \pm 0.11^{\mathrm{f}}$ & $0.66 \pm 0.11^{\mathrm{e}}$ & $0.86 \pm 0.15^{\mathrm{cd}}$ & $1.00 \pm 0.01 b^{c}$ & $1.48 \pm 0.18^{b}$ & $2.28 \pm 0.19^{\mathrm{a}}$ & $1.33 \pm 0.11^{\mathrm{b}}$ & 61.76 \\
\hline WG (g) & $0.45 \pm 0.06^{\mathrm{e}}$ & $0.67 \pm 0.05^{\mathrm{d}}$ & $0.89 \pm 0.06^{\mathrm{c}}$ & $1.18 \pm 0.28^{b}$ & $1.35 \pm 0.37^{b}$ & $1.56 \pm 0.31^{\mathrm{a}}$ & $1.27 \pm 0.03^{\mathrm{ab}}$ & 25.16 \\
\hline SGR (\%) & $2.65 \pm 0.06^{\mathrm{d}}$ & $2.81 \pm 0.09^{c}$ & $2.93 \pm 0.15^{\mathrm{bc}}$ & $3.05 \pm 0.09^{\mathrm{ab}}$ & $3.10 \pm 0.13^{\mathrm{ab}}$ & $3.17 \pm 0.11^{\mathrm{a}}$ & $3.09 \pm 0.11^{\mathrm{ab}}$ & 7.62 \\
\hline
\end{tabular}

Initial morphometric data: $1.1 \pm 0.05 \mathrm{~cm}$ length; $0.05 \pm 0.006 \mathrm{~g}$ weight.

Each value is mean $\pm \mathrm{SD}$ of three individual observations.

Mean values within the same row sharing different alphabetical letter superscripts are statistically significant at $\mathrm{P}<0.05$ (one-way ANOVA and subsequent post hoc multiple comparison with DMRT).

SR, survival rate; LG, length gain; WG, weight gain, SGR, specific growth rate
Activities of digestive enzymes and contents of basic biochemical constituents

Activities of digestive enzymes, such as protease, amylase and lipase, and the concentrations of basic biochemical constituents, such as total protein, amino acids, carbohydrate, and lipids were found to be significantly $(P<0.05)$ elevated in $E$. gallinarum enriched Artemia nauplii fed prawns when compared with un-enriched Artemia and artificial pelletized feed. Among the different concentrations, $847 \times 10^{-7} E$. gallinarum enriched Artemia nauplii produced significantly the best performance than that of other concentrations (Table 3). 
Jain IB et al., Sch Acad J Biosci, Feb, 2020; 8(2): 13-22

Table-3: Concentrations of biochemical constituents and activities of digestive enzymes in M. rosenbergii PL fed with pelletized feed, un-enriched and $E$. gallinarum enriched Artemia nauplii for 45 days.

\begin{tabular}{|c|c|c|c|c|c|c|c|c|c|}
\hline \multirow{2}{*}{\multicolumn{2}{|c|}{ Parameter }} & \multirow{3}{*}{$\begin{array}{c}\begin{array}{c}\text { Pelletized } \\
\text { feed }\end{array} \\
38.64 \pm \\
0.64^{\mathrm{e}}\end{array}$} & \multirow{3}{*}{$\begin{array}{l}\begin{array}{l}\text { PL fed with } \\
\text { Un-enriched } \\
\text { Artemia } \\
\text { nauplii } \\
45.44 \pm \\
1.15^{\mathrm{e}}\end{array}\end{array}$} & \multicolumn{5}{|c|}{ PL fed with $E$. gallinarum enriched Artemia nauplii } & \multirow{3}{*}{$\begin{array}{c}\text { F-value } \\
89.77\end{array}$} \\
\hline & & & & \multirow{2}{*}{$\begin{array}{c}2^{2078 \times 10^{-1}} \\
\text { CFU } \\
60.59 \pm \\
1.52^{\mathrm{d}}\end{array}$} & \multirow{2}{*}{$\begin{array}{c}\text { 1774x10 }^{-3} \\
\text { CFU } \\
65.89 \pm \\
9.12^{\mathrm{d}}\end{array}$} & \multirow{2}{*}{ 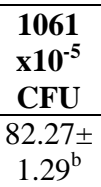 } & \multirow{2}{*}{$\begin{array}{c}847 \times 10^{-7} \\
\text { CFU } \\
104.86 \pm \\
1.54^{\mathrm{a}}\end{array}$} & \multirow{2}{*}{$\begin{array}{c}547 \times 10^{-9} \\
\text { CFU } \\
67.23 \pm \\
1.28^{\mathrm{c}}\end{array}$} & \\
\hline \multirow{4}{*}{$\begin{array}{l}\text { Biochemical } \\
\text { constituents } \\
\text { (mg/g wet wt.) }\end{array}$} & Protein & & & & & & & & \\
\hline & $\begin{array}{c}\text { Amino } \\
\text { acid }\end{array}$ & $\begin{array}{c}21.69 \pm \\
1.68^{\mathrm{e}} \\
\end{array}$ & $\begin{array}{c}24.00 \pm \\
1.19^{\mathrm{d}} \\
\end{array}$ & $\begin{array}{c}32.93 \pm \\
1.04^{\mathrm{c}} \\
\end{array}$ & $\begin{array}{c}44.24 \pm \\
2.6^{\mathrm{b} 0} \\
\end{array}$ & $\begin{array}{c}53.43 \pm \\
1.60^{\mathrm{b}} \\
\end{array}$ & $\begin{array}{c}64.61 \pm \\
1.21^{\mathrm{a}} \\
\end{array}$ & $\begin{array}{c}51.38 \pm \\
0.71^{\mathrm{b}} \\
\end{array}$ & 31.58 \\
\hline & $\begin{array}{c}\text { Carbo- } \\
\text { hydrate }\end{array}$ & $\begin{array}{l}12.28 \pm \\
0.72^{\mathrm{d}} \\
\end{array}$ & $\begin{array}{c}14.69 \pm \\
1.50^{\mathrm{e}} \\
\end{array}$ & $\begin{array}{c}17.99 \pm \\
0.61^{\mathrm{c}} \\
\end{array}$ & $\begin{array}{c}20.60 \pm \\
1.82^{\mathrm{b}} \\
\end{array}$ & $\begin{array}{c}24.80 \pm \\
0.98^{\mathrm{ab}} \\
\end{array}$ & $\begin{array}{c}29.97 \pm \\
0.99^{\mathrm{a}} \\
\end{array}$ & $\begin{array}{c}22.32 \pm \\
0.14^{\mathrm{b}} \\
\end{array}$ & 30.26 \\
\hline & Lipid & $\begin{array}{l}5.18 \pm \\
0.24^{\mathrm{d}}\end{array}$ & $\begin{array}{l}6.92 \pm \\
0.36^{\mathrm{e}}\end{array}$ & $\begin{array}{l}8.72 \pm \\
0.23^{\mathrm{c}}\end{array}$ & $\begin{array}{c}10.84 \pm \\
0.23^{\mathrm{c}}\end{array}$ & $\begin{array}{c}13.20 \pm \\
0.23^{\mathrm{b}}\end{array}$ & $\begin{array}{c}15.47 \pm \\
0.50^{\mathrm{a}}\end{array}$ & $\begin{array}{c}12.04 \pm \\
0.22^{\mathrm{c}}\end{array}$ & 11.93 \\
\hline \multirow{3}{*}{$\begin{array}{c}\text { Digestive } \\
\text { enzymes } \\
\text { (U/ mg } \\
\text { protein) }\end{array}$} & Protease & $\begin{array}{l}1.44 \pm \\
0.04^{\mathrm{f}}\end{array}$ & $\begin{array}{l}1.53 \pm \\
0.07^{\mathrm{e}}\end{array}$ & $\begin{array}{l}1.84 \pm \\
0.05^{\mathrm{d}}\end{array}$ & $\begin{array}{c}1.95 \pm \\
0.1^{\mathrm{c}}\end{array}$ & $\begin{array}{l}2.45 \pm \\
0.09^{\mathrm{b}}\end{array}$ & $\begin{array}{l}2.68 \pm \\
0.12^{\mathrm{a}}\end{array}$ & $\begin{array}{l}2.27 \pm \\
0.08^{\mathrm{b}}\end{array}$ & 325.71 \\
\hline & Amylase & $\begin{array}{l}0.62 \pm \\
0.08^{\mathrm{e}}\end{array}$ & $\begin{array}{l}0.74 \pm \\
0.05^{\mathrm{f}}\end{array}$ & $\begin{array}{c}0.92 \pm \\
0.1^{\mathrm{d}}\end{array}$ & $\begin{array}{l}1.23 \pm \\
0.08^{c}\end{array}$ & $\begin{array}{c}1.38 \pm \\
0.2^{\mathrm{b}}\end{array}$ & $\begin{array}{l}1.58 \pm \\
0.06^{\mathrm{a}}\end{array}$ & $\begin{array}{l}1.22 \pm \\
0.11^{\mathrm{c}}\end{array}$ & 58.00 \\
\hline & Lipase* $^{*}$ & $\begin{array}{l}0.12 \pm \\
0.03^{\mathrm{f}}\end{array}$ & $\begin{array}{l}0.18 \pm \\
0.05^{\mathrm{e}}\end{array}$ & $\begin{array}{l}0.28 \pm \\
0.08^{d}\end{array}$ & $\begin{array}{l}0.49 \pm \\
0.07^{\mathrm{d}}\end{array}$ & $\begin{array}{l}0.57 \pm \\
0.08^{\mathrm{b}}\end{array}$ & $\begin{array}{l}0.64 \pm \\
0.07^{\mathrm{a}}\end{array}$ & $\begin{array}{l}0.51 \pm \\
0.05^{\mathrm{c}}\end{array}$ & 170.65 \\
\hline
\end{tabular}

Each value is mean \pm standard deviation of three individual observations. $*$, unit $\times 10^{3}$

Mean values within the same row sharing different alphabetical letter superscripts are statistically significant at $\mathrm{P}<0.05$ (one-way ANOVA and subsequent post hoc multiple comparison with DMRT

Zokaeifar et al. [26] reported that B. subtilis strains L10 and G1 have the ability to increase digestive enzyme activities in the gastrointestinal tract of shrimp (Litopenaeus vannamei) fed with these B. subtilis strains L10 and G1 supplemented diets. Digestive enzymes are among the most important factors that influence the efficiency of feed utilization in fish and hence characterization of these enzymes provides important information regarding the digestive capacity of fish to hydrolyze carbohydrates, proteins and lipids in feed ingredients [27]. Suzer et al. [28] suggested that the probiotics can influence digestive processes by enhancing the population of beneficial microorganisms, improving the intestinal microbial balance and microbial enzyme activity, consequently improving the digestibility and absorption of food and feed utilization, which was demonstrated in this study by better growth performance and survival rate in treated groups.

\section{Analysis of gut microbial consortium}

In the un-enriched Artemia fed prawn gut, the presence of Escherichia coli, Klebsiella sp., Citrobacter sp., Acetinobacter sp., Streptococcus sp., Bacillus sp., Staphylococcus sp., and Pseudomonas sp., were identified through colony morphology and biochemical tests. In the gut of PL fed with $847 \times 10^{-7}$ concentration of E. gallinarum enriched Artemia produced the presence of Enterococcus sp., E. coli, Bacillus sp., Streptococcus sp., and Klebsiella sp., were identified through colony morphology and biochemical tests. Thus, the study concluded that, Citrobacter sp., Acinetobacter sp., Staphylococcus sp., and Pseudomonas sp., were competitively excluded by Enterococcus sp., Finally, probiotic bacteria Enterococcus sp., was identified and confirmed in the gut of prawn (Table 4-5; Fig. 4-5). 
Table-4: Confirmative results of biochemical tests for micro flora present in the gut of $M$. rosenbergii PL fed with $847 \times 10^{-7}$ CFU of $E$. gallinarum enriched Artemia nauplii

\begin{tabular}{|c|c|c|c|c|c|c|c|c|c|c|c|c|c|c|}
\hline \multirow[b]{2}{*}{ Test } & \multirow[b]{2}{*}{ Eg } & \multicolumn{8}{|c|}{ Un-enriched Artemia nauplii fed PL gut } & \multicolumn{5}{|c|}{$\begin{array}{l}\text { E. gallinarum enriched Artemia nauplii } \\
\text { fed PL gut }\end{array}$} \\
\hline & & $E c$ & $\begin{array}{c}K \\
\text { sp. }\end{array}$ & $\begin{array}{c}C \\
\text { sp. }\end{array}$ & $\begin{array}{c}A \\
\text { sp. }\end{array}$ & $\begin{array}{l}\text { Ste } \\
\text { sp. }\end{array}$ & $\begin{array}{c}B \\
\text { sp. }\end{array}$ & $\begin{array}{l}P \\
\text { sp. }\end{array}$ & $\begin{array}{l}\text { Sta } \\
\text { sp. }\end{array}$ & $E \mathbf{s p}$ & $E c$ & $B$ sp. & $\begin{array}{l}\text { Sta } \\
\text { sp. }\end{array}$ & $\begin{array}{c}K \\
\text { sp. }\end{array}$ \\
\hline Gram's staining & - & - & + & - & + & + & + & - & + & + & - & + & + & + \\
\hline Motility test & + & + & + & + & + & + & + & + & + & - & + & + & + & + \\
\hline Indole test & + & + & + & - & + & - & - & - & - & - & + & - & - & + \\
\hline Methyl red test & + & + & + & + & + & - & - & - & - & - & + & - & - & + \\
\hline Vp test & - & - & + & - & - & + & - & - & + & + & - & - & + & + \\
\hline $\begin{array}{l}\text { Citrate } \\
\text { utilization test }\end{array}$ & - & - & - & + & - & + & + & + & + & - & - & + & + & - \\
\hline $\begin{array}{l}\text { Starch } \\
\text { hydrolases }\end{array}$ & + & + & - & - & - & + & + & - & + & - & + & + & + & - \\
\hline $\begin{array}{l}\text { Gelatin } \\
\text { hydrolases }\end{array}$ & + & + & - & - & - & + & + & + & + & - & + & + & + & - \\
\hline $\begin{array}{l}\text { Nitrate reduction } \\
\text { test }\end{array}$ & + & + & + & + & + & + & + & + & + & + & + & + & + & + \\
\hline Oxidase test & + & + & - & - & - & - & - & + & - & - & + & - & - & - \\
\hline Catalase test & - & - & $\mathrm{A}$ & + & + & $\mathrm{A}$ & + & + & A & - & - & + & $\mathrm{A}$ & $\mathrm{A}$ \\
\hline Glucose test & A & A & $\mathrm{A}$ & + & + & A & $\mathrm{A}$ & A & A & + & A & A & $\mathrm{A}$ & A \\
\hline Lactose test & A & $\mathrm{A}$ & $\mathrm{A}$ & + & + & $\mathrm{A}$ & $\mathrm{A}$ & NA & A & + & A & $\mathrm{A}$ & $\mathrm{A}$ & $\mathrm{A}$ \\
\hline Sucrose test & A & $\mathrm{A}$ & $\mathrm{A}$ & + & - & $\mathrm{A}$ & $\mathrm{A}$ & A & $\mathrm{A}$ & - & $\mathrm{A}$ & $\mathrm{A}$ & $\mathrm{A}$ & $\mathrm{A}$ \\
\hline Manitol test & $\mathrm{A}$ & $\mathrm{A}$ & $\mathrm{A}$ & + & - & $\mathrm{A}$ & $\mathrm{A}$ & A & $\mathrm{A}$ & - & $\mathrm{A}$ & $\mathrm{A}$ & $\mathrm{A}$ & $\mathrm{A}$ \\
\hline Maltose test & NA & NA & $\mathrm{A}$ & + & - & NA & $\mathrm{A}$ & A & NA & + & NA & A & NA & $\mathrm{A}$ \\
\hline
\end{tabular}

+, Positive; -, Negative; A, Acid production; NA, No acid production. Ec, Escherichia coli; P.sp. Pseudomonas sp.; Ste.sp, Streptococcus sp.; K.sp, Klebsiella sp.; B.sp, Bacillus sp.; C.sp, Citrobacter sp,; A.sp. Acetinobacter sp,; Sta.sp, Staphylococcus sp,; E.sp, Enterococcus sp,

The bacterial biomass mixed with feed might help in colonization in the intestine to perform competitive exclusion mechanism in shrimp [29], and colonization with specific microbiota may play a role in balancing the intestinal mucosal immune system, which may contribute towards the induction and maintenance of immunological tolerance or inhibition of the deregulated responses induced by pathogens in the host [3]. Bacillus, when used as a probiotic, was able to inhibit pathogens by colonizing both the culture water and $P$. mondon and $P$. vannamei, digestive tract to exclude other harmful bacteria producing an anti-bacterial substance or activating both cellar and humoral immune defences [30,31]. For bacteria to be considered probiotic it must be capable of surviving passage through the gastrointestinal tract. It must then colonize the host digestive system, either by adhering to the mucous membrane surface or the intestinal epithelia. Finally, it must be able to produce inhibitory or antagonist metabolites against undesirable native flora, and reproduce [32-34]. Recently a marine bacterial strain, Pseudomonas I2, was isolated from estuarine environmental samples that produced inhibitory compounds against shrimp pathogenic vibrios. This antibacterial compound was shown to be of low molecular weight, heat stable, soluble in chloroform, and resistant to proteolytic enzymes [35]. Such a mechanism may be prevailed in the present results as well.

\section{CONCLUSION}

In this study, E. gallinarum has get colonized in the gut of $M$. rosenbergii, eliminated some pathogenic bacteria and enhanced the survival and growth performance. Therefore, it can be used as a probiotic bacterium for sustainable culture and development of Macrobrachium. 


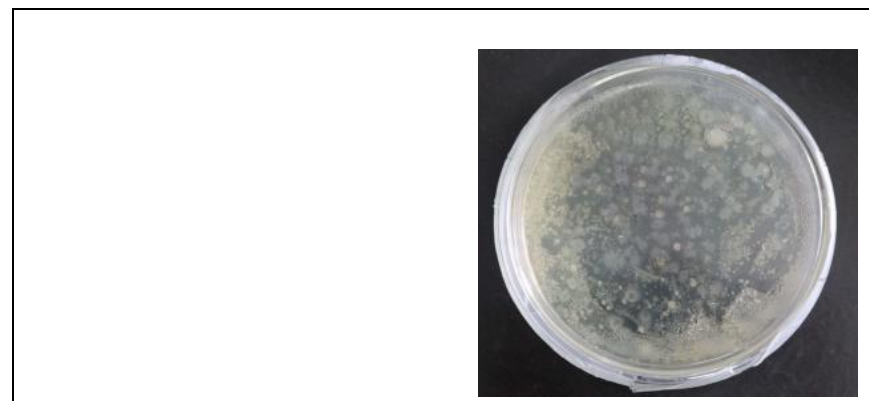

1. Mass culture

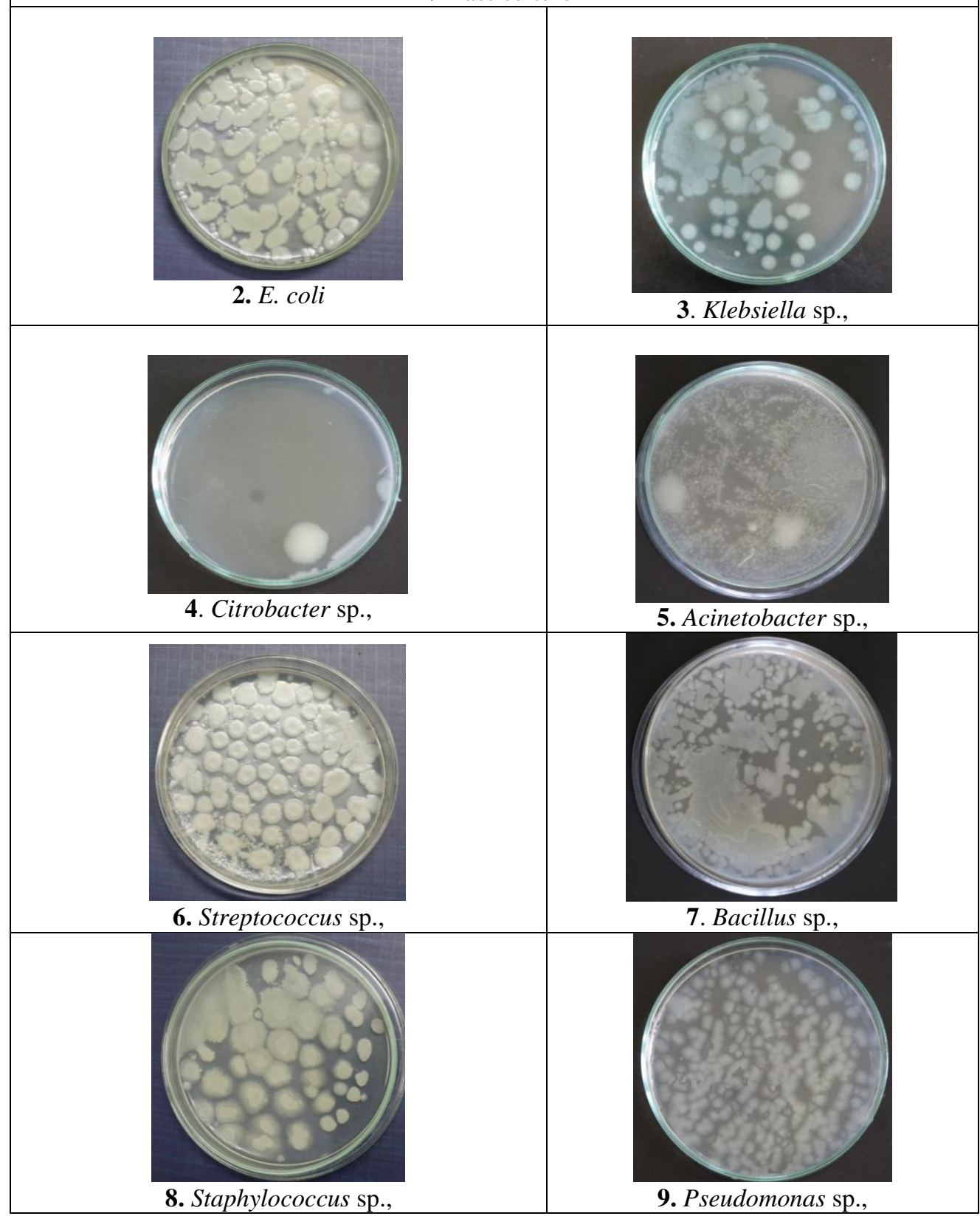

Fig-4: Agar plate morphology of different bacterial culture from the gut of M. rosenbergii PL fed with un-enriched Artemia nauplii 


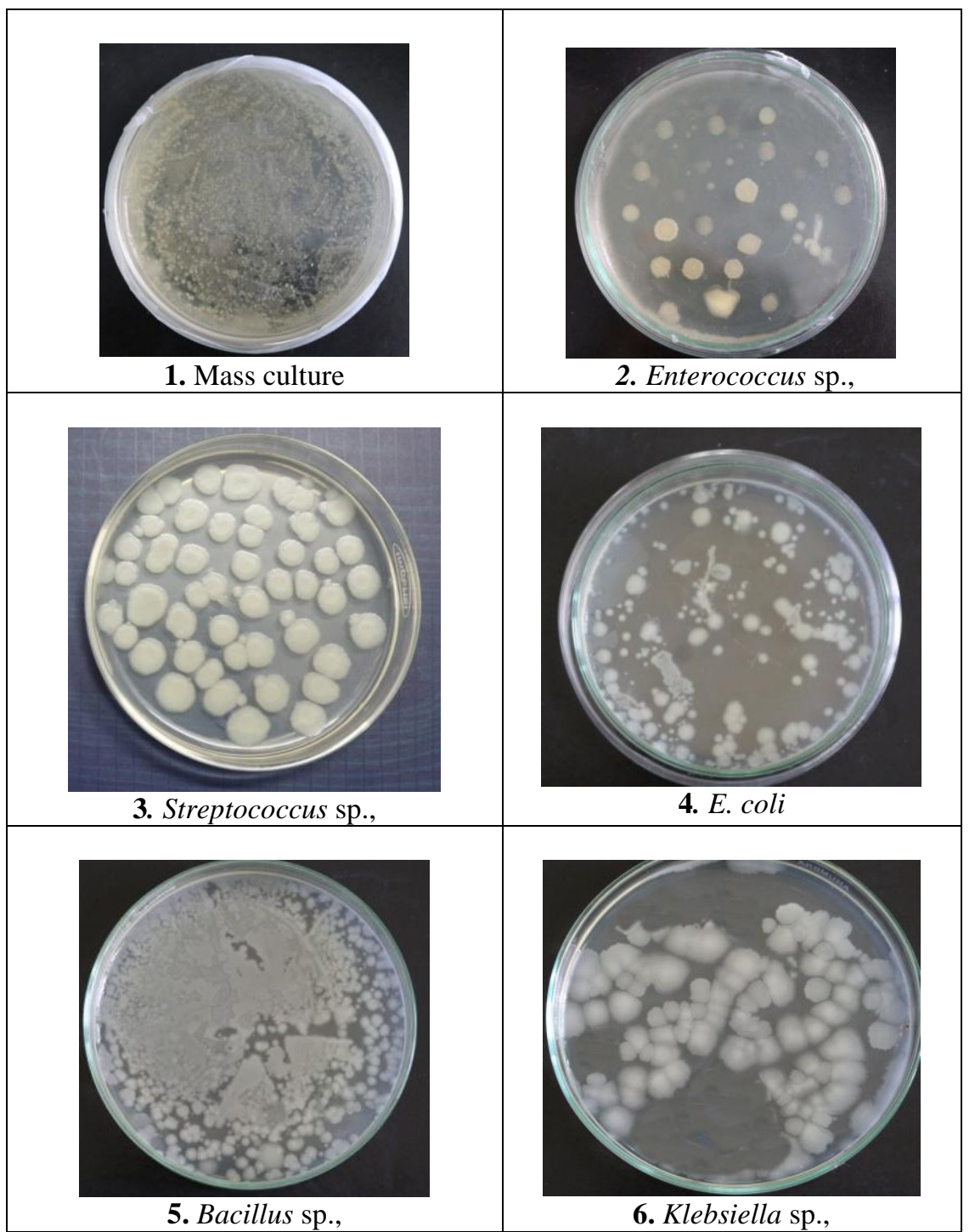

Fig-5: Agar plate morphology of different bacterial culture from the gut of M. rosenbergii PL fed with E. gallinarum (CFU 847x10 $\left.{ }^{-7}\right)$ enriched Artemia nauplii

Table-5: Bacterial consortium in the gut of $M$. rosenbergii PL fed with un-enriched and 847x10 ${ }^{-7} \mathrm{CFU}$ of $E$. gallinarum enriched Artemia nauplii

\begin{tabular}{|l|l|c|}
\hline \multicolumn{1}{|c|}{ Samples } & Identified species & Composition (\%) \\
\hline \multirow{5}{*}{ Un-enriched Artemia nauplii fed PL gut } & E. coli & 10 \\
\cline { 2 - 3 } & Klebsiella sp., & 8 \\
\cline { 2 - 3 } & Citrobacter sp., & 15 \\
\cline { 2 - 3 } & Acinetobacter sp., & 12 \\
\cline { 2 - 3 } & Streptococcus sp., & 11 \\
\cline { 2 - 3 } & Bacillus sp., & 18 \\
\cline { 2 - 3 } & Staphylococcus sp., & 10 \\
\cline { 2 - 3 } & Pseudomonas sp., & 11 \\
\cline { 2 - 3 } & Total & $\mathbf{9 3}$ \\
\hline \multirow{5}{*}{ E. gallinarum enriched Artemia nauplii fed PL gut } & 34 \\
\cline { 2 - 3 } & Enterococcus sp., & 10 \\
\cline { 2 - 3 } & Streptococcus sp., & 21 \\
\cline { 2 - 3 } & E. coli & 21 \\
\cline { 2 - 3 } & Bacillus sp., & 12 \\
\cline { 2 - 3 } & Klebsiella sp., & $\mathbf{9 7}$ \\
\cline { 2 - 3 } & Total & \\
\hline
\end{tabular}




\section{ACKNOWLEDGMENTS}

The first author is gratefully acknowledging Bharathiar University, Coimbatore, India for providing Research facility. The Science and Engineering Research Board, Department of Science and Technology, Government of India, is gratefully acknowledged for the financial support provided in the form of research project (SB/EMEQ-291/2013 of the SERB, New Delhi).

\section{REFERENCES}

1. FAO. The State of World Fisheries and Aquaculture (SOFIA): Contributing to food security and nutrition for all, Rome: Food and Agriculture Organization. 2016: 200.

2. Sanchez-Paz A, Garcia-Carreno LF, Muhlia-Almazan A, Hernandez-Saavedra N, Yepiz-Plascencia G. Differential expression of trypsin mRNA in the white shrimp (Penaeus vannamei) midgut gland under starvation conditions. Journal of Experimental Marine Biology and Ecology. 2006; 292:1-7

3. Gatesoupe FJ. The use of probiotics in aquaculture. Aquaculture. 1999; 180:147-165.

4. Moriarty DJW. Disease control in shrimp aquaculture with probiotic bacteria. In: Bell CR, Brylinsky M, and Johnson-Green P. (Eds.), Microbial Biosystems: New Frontiers: Proceedings of the 8th International Sympo-sium on Microbial Ecology. Atlantic Canada Society for Microbial Ecology, Halifax, Canada, 1999.

5. Nikoskelainen S, Ouwehand AC, Bylund G, Salminen S, Lilius EM. Immune enhancement in rainbow trout (Oncorhynchus mykiss) bypotential probiotic bacteria (Lactobacillus rhamnosus). Fish and Shellfish Immunology. 2003; 15:443-452.

6. Fisher K, Phillips C. The ecology, epidemiology and virulence of Enterococcus. Microbiology. 2009; 155:1749-1757.

7. Foulquie Moreno MR, Sarantinopoulos P, Tsakalidou E, De Vuyst L. The role and application of Enterococci in food and health. International Journal of Food Microbiology. 2006; 106:1-24.

8. Franz CM, Huch M, Abriouel H, Holzapfel W, Gálvez A. Enterococci as probiotics and their implications in food safety. 2011.

9. Cai YM, Suyanandana P, Saman P, Benno Y. Classification and characterization of lactic acid bacteria isolated from the intestine of common carp and freshwater prawns, Journal of Genetics and Applied Microbiology. 1999; 45:177-184.

10. Tekinay AA, Davies SJ. Dietary carbohydrate level influencing feed intake, nutrient utilisation and plasma glucose concentration in the rainbow trout, (Oncorhynchus mykiss Walbaum, 1792. Turkish Journal of Veterinary and Animal Sciences. 2001; 25:657-666.
11. Lowry OH, Rosebrough WJ, Fair AL, Randall RJ. Protein measurement with the folin phenol reagent. Journal of Biological Chemistry. 1951; 193:265-275.

12. Moore S, Stein WH. Methods in enzymol (Eds: Olowick, Spand Kalpan, ND) Academic press New York.pp. 1984; 468.

13. Roe JH. The determination of sugar and blood and spinal fluid with anthrone reagent. Journal of Biological Chemistry. 1995; 212:335-343.

14. Folch J, Lees M, Bloane-Stanely GH. A Simple method for the isolation and purification of total lipids from animal tissues. Journal of Biological Chemistry. 1957; 266:497-509.

15. Barnes H, Blackstock J. Estimation of lipids in marine animals and tissues. Detail investigation of the sulpho phosphovanillin method for total lipids. Journal of Experimental Marine Biology and Ecology. 1973; 12:103-118.

16. AOAC. 1995. Official methods of analysis of Association of Analytical Communities international. 2 vol. $16^{\text {th }}$ Edn. Arlington, VA, USA.

17. Furne M, Hidalgo MC, Lopez A, Garcia Gal lego M, Morales AE, Domezain A. Digestive enzyme activities in adriaticsturgeon Acipenser naccarii and rainbow trout Oncorhynchus mykiss. A comparative study. Aquaculture. 2005; 250:391-398.

18. Bernfeld P. Amylases, in: Colowick S.P., Kaplan N.O., (Eds.), Methods in Enzymology. Academic Press, New York. 1955:149-158.

19. Holt JG, Krie NR, Sneath PHA, Stately JT, Williams ST. Bergey's Manual of Determinative Bacteriology, 9 th Edn., Baltimore, Williams and Wilkins. 1996; 787.

20. Mahmood A, Saeed M, Nasrollah A, Seyed HH. The effects of feeding with synbiotic (Pediococcus acidilactici and fructooligosac charide) enriched adult Artemia on skin mucus immune responses, stress resistance, intestinal microbiota and performance of angelfish (Pterophyllum scalare). Fish \& Shellfish Immunology. 2016; 54:516-522.

21. Salem Ahmed Md, Nour AM, Srour TM, Assem SS, Ibrahim HA, El-Sayed HS. Greenwater, Marine Bacillus subtilis HS1 Probiotic and Synbiotic Enriched Artemia and Rotifers Improved European Seabass Dicentrarchus labrax Larvae Early Weaning Length Growth, Survival, Water and Bacteriology quality. American Journal of Life Sciences. 2015; 3(6-1):45-52.

22. Bhavan PS. Devi VG. Shanthi R. Radhakrishnan S. Poongodi R. Basic biochemical constituents and profiles of amino acids in the post larvae of Macrobrachium rosenbergii Fed with Spirulina and Yeast enriched Artemia. International Journal of Science and Research. 2010; 2(3):539-547.

23. Seenivasan C, Saravana Bhavan P, Radhakrishnan S. Effect of probiotics (Binifit ${ }^{T M}$ ) on survival, growth, biochemical constituents and energy budget of the freshwater prawn Macrobrachium rosenbergii post larvae. Elixir Aquaculture. 2011; 41:5919-5927. 
24. Seenivasan C, Saravana Bhavan P, Radhakrishnan S, Shanthi R. Enrichment of Artemia nauplii with Lactobacillus sporogenes for enhancing the survival, growth and levels of biochemical of constituents in the post-larvae of freshwater prawn Macrobrachium rosenbergii. Turkish Journal of Fisheries and Aquatic Sciences. 2012a; 12:23-31.

25. Liu $\mathrm{CH}$, Chiu $\mathrm{CH}$, Wang SW. Cheng Dietary administration of the probiotic, Bacillus subtilis E20, enhances the growth, innate immune responses, and disease resistance of the grouper, Epinephelus coioides, Fish \& Shellfish Immunology. 2012; 33:699-706.

26. Zokaeifar H, Balcazar JL, Saad CR, Kamarudin MS, Sijam K, Arshad A, Nejat N. Effects of Bacillus subtilis on the growth performance, digestive enzymes, immune gene expression and disease resistance of white shrimp, Litopenaeus vannamei. Fish \& Shellfish Immunology. 2012; 33:683-689.

27. Lemieux H, Blier P, Dutil JD. Do digestive enzymes set a physiological limit on growth rate and food conversion efficiency in the Atlantic cod (Gadusmorhua). Fish Physiology and Biochemistry. 1999; 20:293-303.

28. Suzer C, Çoban D, Okan Kamaci H, Saka Ş, Firat K, Otgucuoğlu O, Küçüksari H. Lactobacillus spp. bacteria as probiotics in gilthead sea bream (Sparus aurata, L.) larvae: Effects on growth performance and digestive enzyme activities, Aquaculture. 2008; 280:140-145.
29. Rengpipat S, Rukpratanporn S, Piyatiratitivorakul $\mathrm{S}$, Menasaveta P. Immunity enhancement in black tiger shrimp (Penaeus monodon) by a probiont bacterium (Bacillus S11). Aquaculture. 2000; 191:271-288.

30. Rengpipat S, Phianphak W, Piyatiratitivorakul S, Menasveta P. Effects of a probiotic bacterium on black tiger shrimp Penaeus monodon survival and growth. Aquaculture. 1998; 167:301-313.

31. Mariel G, Fabiano T, Jenny R. Selection of probiotic bacteria and study of their immunostimulatory effect in Penaeus vannamei. Aquaculture. 2004; 233:1-14.

32. Thompson WG, Longstreth GF, Drossman DA, Heaton KW, Irvine EJ, Muller-Lissner SA. Functional bowel disorders and functional gastrointestinal disorders. Gut. 1999; 45:11431147.

33. Verschuere L, Rombaut G, Huys G, Dhont J, Sorgeloos P, Verstraete W. Probiotic bacteria as biological control agents in aquaculture, review. 2000; 64:655- 671.

34. Ziaei-Nejad S, Rezaei MH, Takami GA, Lovett DL, Mirvaghefi AR, Shakouri M. The effect of Bacillus spp. bacteria used as probiotics on digestive enzyme activity, survival and growth in the Indian white shrimp Fenneropenaeus indicus. Aquaculture. 2006; 252:516-524.

35. Chythanya R, Karunasagar I, Karunasagar I. Inhibition of shrimp pathogenic vibrios by a marine Pseudomonas I 2 strain. Aquaculture. 2002; 208:110 . 